\title{
The role of CD95 and CD95 ligand in cancer
}

\author{
ME Peter ${ }^{\star, 1}$, A Hadji ${ }^{1,2}$, AE Murmann ${ }^{1}$, S Brockway ${ }^{1}$, W Putzbach ${ }^{1}$, A Pattanayak ${ }^{1}$ and P Ceppi ${ }^{1}$
}

CD95 (Fas/APO-1) and its ligand, CD95L, have long been viewed as a death receptor/death ligand system that mediates apoptosis induction to maintain immune homeostasis. In addition, these molecules are important in the immune elimination of virus-infected cells and cancer cells. CD95L was, therefore, considered to be useful for cancer therapy. However, major side effects have precluded its systemic use. During the last 10 years, it has been recognized that CD95 and CD95L have multiple cancer-relevant nonapoptotic and tumor-promoting activities. CD95 and CD95L were discovered to be critical survival factors for cancer cells, and were found to protect and promote cancer stem cells. We now discuss five different ways in which inhibiting or eliminating CD95L, rather than augmenting, may be beneficial for cancer therapy alone or in combination with standard chemotherapy or immune therapy.

Cell Death and Differentiation (2015) 22, 549-559; doi:10.1038/cdd.2015.3; published online 6 February 2015

\section{Facts}

- CD95 is a surface receptor that has the capacity to mediate apoptosis induction in cancer cells.

- To induce apoptosis, CD95 recruits a number of proapoptotic factors including caspase-8 to form the death-inducing signaling complex when stimulated by CD95 ligand (CD95L).

- Immune cells (i.e., cytotoxic killer and natural killer cells) use CD95L as one mechanism to kill cancer cells or virusinfected cells.

- Most cancer cells are resistant to CD95-mediated apoptosis.

- CD95L can not be used systemically for cancer therapy because of the side effects due to apoptosis induction in hepatocytes.

\section{Open Questions}

- Why do most if not all cancer cells express both CD95 and CD95L?

- Why do cancer cells acquire mutations in CD95 usually only in one allele?

- Why are the cancer cells that are sensitive to CD95mediated apoptosis (at least in vitro) among the most sensitive of any cells?

\section{CD95/CD95L in the Immune System}

CD95 (Fas/APO-1/TNFRSF6), a cell surface protein that belongs to the tumor necrosis factor receptor family, can mediate apoptosis when bound to its natural ligand, CD95L (CD178/TNFSF6) or stimulated with agonistic antibodies. It is ubiquitously expressed in the body, but is particularly abundant in the thymus, liver, heart, and kidney. CD95L is predominantly expressed in activated $\mathrm{T}$ lymphocytes and natural killer cells, and is constitutively expressed in tissues of 'immune-privilege sites' such as the testis and eye. ${ }^{1}$ Experiments with mutant mice have demonstrated the importance of CD95-mediated apoptosis in the maintenance of cell homeostasis and in the deletion of useless or autoreactive T cells. ${ }^{1-3}$ A mutation found in the Ipr (lymphoproliferation) mouse strain causes defective expression of CD95. Lpr mice develop lymphadenopathy and suffer from a systemic lupus erythematosus-like autoimmune disease. ${ }^{4} \mathrm{~A}$ second mouse strain (gld, generalized lymphoproliferative disease) expresses a mutant form of CD95L. Gld mice have an abnormal phenotype similar to Ipr mice, which includes Ipr and autoimmune disease. ${ }^{5}$ Complete knockout mice lacking either CD95 or CD95L expression also show an autoimmune phenotype that is more pronounced than the one seen in Ipr or gld mice. ${ }^{6-8} \mathrm{~A}$ third mutant mouse strain with an Ipr-like phenotype (Iprcg) was found to have a point mutation ( $T$ to $A$ ) in the center of the CD95 cytoplasmic region. This mutation generates a receptor in which the ability to transduce an apoptotic signal is blocked. ${ }^{9}$ In a related human condition, autoimmune lymphoproliferative syndrome (ALPS), ${ }^{10}$ ALPS type la patients carry dominant-negative mutations in CD95 and type $\mathrm{lb}$ patients have mutations in CD95L, resembling mice with Iprcg and gld mutations, respectively.

\footnotetext{
${ }^{1}$ Division Hematology/Oncology, Feinberg School of Medicine, Northwestern University, Chicago, IL, USA

${ }^{*}$ Corresponding author: ME Peter, Division of Hematology/Oncology, Feinberg School of Medicine, Northwestern University, 303 East Superior Street, Lurie-6-123, Chicago, IL 60611, USA. Tel: +1 312503 1291; Fax: +1 312503 0189; E-mail: m-peter@northwestern.edu

${ }^{2}$ Current address: Department of Pediatrics, Section of Hematology/Oncology/Stem Cell Transplantation, University of Chicago, Chicago, IL 60637, USA.

Abbreviations: ALPS, autoimmune lymphoproliferative syndrome; CTL, cytotoxic lymphocyte; DEN, diethylnitrosamine; CD95L, CD95 ligand; CSC, cancer stem cell; DD, death domain; DICE, death induced by CD95R/L elimination; DISC, death-inducing signaling complex; EGFR, epidermal growth factor receptor; EMT, epithelial-tomesenchymal transition; FADD, Fas-associated with a death domain; CFLIP, cellular FLICE inhibitory protein; Ipr, lymphoproliferation; gld, generalized lymphoproliferative disease; mCD95L, membrane-bound CD95L; MMP, matrix metalloproteinase; PDAC, pancreatic ductal adenocarcinoma; PI3K, phosphoinositide-3 kinase; RIP, receptor interacting protein; sCD95L, soluble CD95L; shRNA, small hairpin RNA; siRNA, small interfering RNA; TNF, tumor necrosis factor; zVAD-fmk, carbobenzoxy-valyl-alanylaspartyl-[O-methyl]- fluoromethylketone

Received 08.12.14; revised 27.12.14; accepted 02.1.15; Edited by G Melino; published online 06.2.15
} 


\section{Canonical Signaling of CD95 in Cancer}

CD95 is predominantly located at the cell surface, where it has been shown to pre-associate in homotrimers. ${ }^{11}$ Similar to all death receptors, CD95 carries a conserved stretch of 80 amino acids in its cytoplasmic tail, the death domain (DD), that is essential for apoptosis initiation. ${ }^{1,12,13}$ Upon binding of CD95L, the CD95 DD assembles the death-inducing signaling complex (DISC) composed of CD95, the adaptor molecule FADD (Fas-associated with a death domain), procaspase-8, procaspase-10, and the caspase-8/10 regulator c-FLIP. ${ }^{13}$ Activated caspase- 8 then initiates the apoptotic program by cleaving various intracellular proteins resulting in the execution of apoptosis. ${ }^{14}$ Likely, the most established proapoptotic activity of CD95 is to mediate the apoptotic death of either virus-infected or cancer cells when engaged by a CD8+ cytotoxic lymphocyte (CTL; Figure 1). In addition to the perforin/granzyme pathway ${ }^{15}$ and some indirect mechanisms involving cytokines such as tumor necrosis factor- $a$ (TNFa) and interferon- $\gamma,{ }^{16-23}$ CD95/CD95L is a direct major system that both CTLs as well as CD4+ cytolytic effector T cells use to eliminate neoplastically transformed cells. ${ }^{24-29}$ CD95 can also mediate receptor interacting protein (RIP)-1-dependent necroptosis under circumstances of caspase inhibition or knockdown of TRAF2. ${ }^{30,31}$ However, the physiological relevance of this activity for cancer has not been established. Expression of CD95 and CD95L by cancer cells implies that they are themselves resistant to CD95-mediated apoptosis. Indeed, most cancer cells are relatively resistant to CD95induced apoptosis even with high levels of CD95 at the surface of the cells. ${ }^{32}$ Cancer cells have multiple ways of becoming resistant to a possible apoptotic insult mediated by CD95. A common mechanism used by the cells is to regulate cell surface expression of the receptor. ${ }^{33,34}$ The CD95 apoptotic signal can also be inhibited at the level of the DISC via increased expression of cFLIP (cellular FLICE inhibitory protein), which can inhibit the interactions of caspase- 8 and -10 with the DISC, ${ }^{35}$ or via reduced expression of FADD ${ }^{36}$ or caspase-8. ${ }^{37,38}$ Loss of apoptosis signaling through CD95 can also be the consequence of deregulation of the expression of the Bcl-2 family proteins or inhibitor of apoptosis proteins, thereby favoring tumor survival. ${ }^{39}$

\section{Other Activities of the Apoptosis-inducing Receptor CD95}

In addition to the activities of CD95 and CD95L in mediating apoptosis induction, mostly in the contest of an immune response, ${ }^{1-3}$ it is now established that CD95 has multiple nonapoptotic activities. ${ }^{40-43}$ For example, CD95 is required for efficient liver regeneration following partial hepatectomy; ${ }^{44,45}$ CD95 activation stimulates renal tubular epithelial cell migration by a $\beta 8$ integrin-dependent mechanism, ${ }^{46}$ and CD95 provides a mitogenic signal in quiescent hepatic stellate cells through activating epidermal growth factor receptor (EGFR). ${ }^{47}$ CD95 is also important for neurite outgrowth. ${ }^{48,49}$ CD95 and CD95L have additional, cancerrelevant, activities. We have identified at least five cancer-relevant activities of CD95 that could be targeted for cancer therapy, and one (apoptosis induction through CD95) that should not be (Figure 2).

Apoptosis induction through CD95. Apoptosis induction is the most well-established activity of CD95, documented by thousands of publications and summarized in numerous review articles (e.g., Nagata, ${ }^{1}$ Peter and Krammer, ${ }^{13}$ and Nagata ${ }^{50}$ ). In the context of cancer, it is relevant that CD95L is one of only a few molecules that immune cells use to activate apoptosis to kill cancer cells (Figure 1). ${ }^{51}$ Apoptosis induction as a cancer cell killing strategy is presumed to be accomplished by tumor-infiltrating lymphocytes expressing CD95L (Figure 2-1, apoptosis). Apoptosis induction in cancer cells through CD95 is the only scenario in which recombinant CD95L could be used for cancer therapy. However, given the fact that almost all established cancers express CD95, and the fact that most cancer cells are resistant to apoptosis induction, we would suggest that stimulating CD95 on cancer cells may not be an effective approach to killing cancer cells. In addition, stimulation of CD95 could never be used therapeutically because of major side effects such as massive apoptosis induction in the liver. ${ }^{52}$ Based on recent

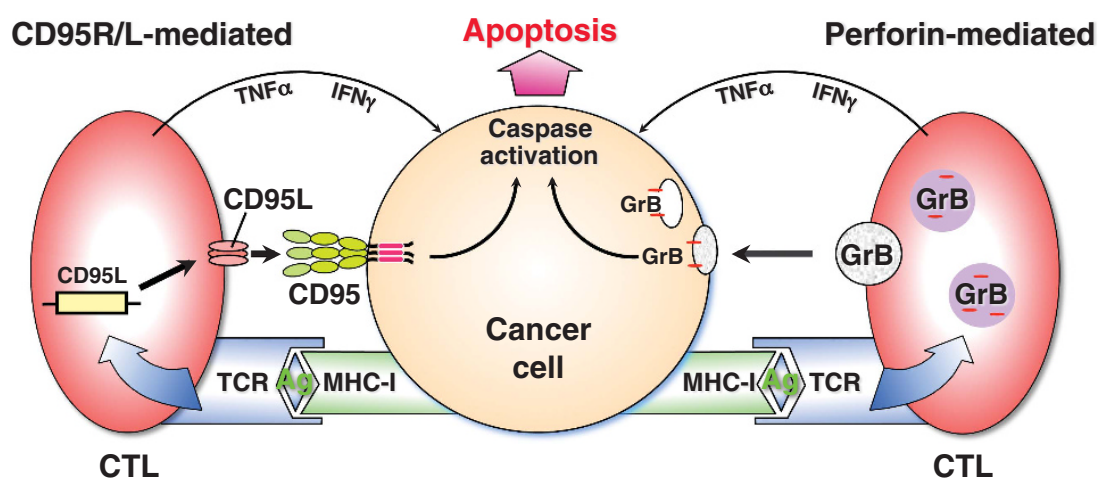

Figure 1 The canonical apoptosis-inducing function of the CD95/CD95L system in killing cancer cells. Cancer cells that are recognized by CTLs in an antigen-specific way are being attacked by direct mechanisms: release of perforin/granzyme (shown as GrB) or use of CD95L to engage CD95 on the surface of cancer cells. Alternatively, indirect mechanisms are activated that result in upregulation of cytokines such as TNF $\alpha$ and INF $\gamma$, which in turn cause upregulation of CD95 and MHC-I (by IFN $\gamma$ ) or induction of cell death through cancer-expressed TNF receptors (by TNF $\alpha$ ). Ag, antigen; CTL, cytotoxic lymphocyte; GrB, granzyme B; IFN $\gamma$, interferon $\gamma$; MHC-I, major histocompatibility complex I; TCR, T-cell receptor; TNF $\alpha$, tumor necrosis factor $\alpha$ 


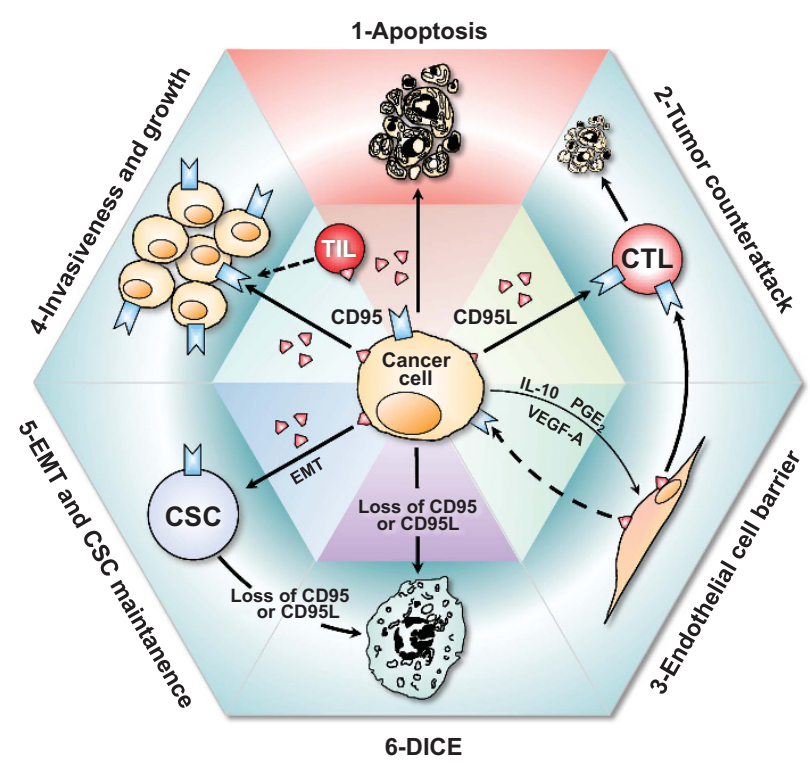

Figure 2 Graphical summary of the role of CD95/CD95L in cancer. Together with the tumor-suppressing ability to trigger apoptosis in (apoptosis sensitive) cancer cells (1), CD95L has a range of tumor-promoting activities, some of which are indirect, such as the suppression of the immune response in the cancer micro-environment by either tumor-generated CD95L (2) or by CD95L expressed by endothelial cells (3), and some of which are direct, such as the promotion of tumor growth and invasiveness (4) or the acquisition of a CSC phenotype (5). Importantly, a lowbaseline level of CD95/CD95L signaling is required for survival of cancer cells. Elimination of CD95/CD95L signaling leads to an irreversible and effective type of cell death, DICE, which predominantly affects CSCs (6). CSC, cancer stem cell, CTL; cytotoxic T lymphocyte; IL-10, interleukin 10; EMT, epithelial-to-mesenchymal transition; PGE2, prostaglandin E2; TIL, tumor-infiltrating lymphocyte; VEGF-A, vascular endothelial growth factor $A$. Stippled arrows indicate hypothetical interactions

data, we propose that inhibiting the activity of CD95L or targeting CD95L mRNA may be more effective for cancer therapy than using CD95L to induce apoptosis in cancer cells:

The tumor strikes back. It has been demonstrated a number of times that expression of CD95L by apoptosisresistant tumor cells enables a powerful 'counterattack' against antitumor immune effector cells, such as cytotoxic killer cells, many of which are themselves sensitive to CD95Lmediated apoptosis ${ }^{53-55}$ (Figure 2-2, tumor counterattack). However, while there is some evidence for the occurrence of this counterattack, its existence remains controversial. ${ }^{56}$ The reported increased concentration of soluble CD95L (sCD95L) in the serum of many cancer patients was often interpreted in the context of the CD95L counterattack theory (Table 1). Upregulation of CD95L in patient sera would suggest a possible immunosuppressive role for this molecule. However, the generalized immune suppression that would be expected from this situation could not be confirmed in cancer patients; thus, it may be that the increase in CD95L expression in tumor tissues has a more direct role in tumor progression.

The tumor endothelium expresses CD95L. Recently, the tumor strikes back concept was rediscovered in a different form. CD95L is expressed on the tumor endothelium in mice and humans ${ }^{57,58}$ (Figure 2-3, endothelial cell barrier).
CD95L was reported to be expressed by tumor epithelium of various human solid cancers but not by normal endothelial cells. ${ }^{59}$ Tumor cells were found to cause upregulation of membrane-bound (m)CD95L on endothelial cells through the action of interleukin 10, prostaglandin E2, and vascular endothelial growth factor A. Interestingly, mCD95L only induced apoptosis of effector killer $\mathrm{T}$ cells but not of regulatory $\mathrm{T}$ cells, which were found to be protected by expression of a number of antiapoptotic proteins including cFLIP, Bcl-2, and Bcl-xL. This finding was supported by a syngeneic in vivo mouse model of ovarian cancer, in which it was demonstrated that expression of CD95L on endothelial cells causes reduced CD8 T-cell infiltration into the tumor. Finally, it was shown that mice treated with a neutralizing antiCD95L antibody show increased infiltration of adoptively transferred tumor vaccine-primed CD8 T cells. ${ }^{59}$ These data suggest that inhibiting endothelial CD95L expression could be a new therapeutic strategy to enhance the potency of adoptive transfer of antitumor $\mathrm{T}$ cells.

The tumor-promoting activities of CD95. Although the concept of inducing apoptosis in cancer cells using death ligands such as CD95L was intriguing, it was unlikely that the only function of CD95 was to induce apoptosis. As early as $1993,{ }^{60}$ it was recognized that CD95 also induces proliferation in various cell types such as $\mathrm{T}$ cells, liver cells, and neurons. ${ }^{45,48,49,61-63}$ In 2004, we reported that stimulation of CD95 on 22 apoptosis-resistant cancer cell lines increases their motility and invasiveness in vitro. ${ }^{64}$ In a study with cells from ALPS patients, as well as cellular and mouse model systems, we demonstrated that nonapoptotic signaling through CD95 involved activation of NF- $\mathrm{BB}$ and the three MAP kinases, Erk1/2, JNK1/2, and p38. ${ }^{64-67}$ In addition, we demonstrated in various cancer cell lines that CD95mediated invasiveness requires activation of NF- $K B$ and ERK, and involves active caspase- 8 and urokinase plasminogen activator. ${ }^{64}$ It is now widely accepted that once cancer cells acquire resistance to CD95-mediated apoptosis, further stimulation of CD95 is tumorigenic (Figure 2-4, invasiveness and growth). ${ }^{64,68-75}$ CD95L is expressed in two flavors, a membrane-bound form and a soluble form that is generated through cleavage of $\mathrm{mCD} 95 \mathrm{~L}$ by metalloproteinases. ${ }^{76,77}$ $\mathrm{mCD} 95 \mathrm{~L}$ in vivo is essential for apoptosis induction, whereas SCD95L has nonapoptotic activities and may be the predominant tumor-promoting activity in vivo. ${ }^{78}$ The concept that CD95 can be a tumor promoter has now gained wide acceptance, supported by a number of reports describing marked activities of CD95 in tumor growth and spread (Table 2).

CD95 is coupled to multiple potentially tumorigenic signaling pathways. CD95 was identified in a small hairpin RNA (shRNA) screen as a modifier that renders human lung adenocarcinomas resistant to EGFR tyrosine kinase inhibitors through activation of NF- $\kappa \mathrm{B} .{ }^{79}$ Others have demonstrated that CD95 mediates invasion via the Src/PI3K/GSK3 $\beta / M M P$ (matrix metalloproteinase) pathway; ${ }^{74,80}$ however, the transactivation of tyrosine kinases by CD95 is incompletely understood. In colon cancer, it was shown that activated CD95 promotes the formation of cell protrusions through a new signaling pathway involving platelet-derived growth factor 
Table 1 Tumor-promoting activities of CD95 and CD95L in clinical studies

\begin{tabular}{|c|c|c|}
\hline Cancer type & Observation & Reference \\
\hline Gynecological malignancies & $\begin{array}{l}\text { aHigh serum CD95 was a negative prognostic marker for cervical, endometrial, and ovarian } \\
\text { cancer }\end{array}$ & ${ }^{\mathrm{b}}$ Konno et al. ${ }^{130}$ \\
\hline $\begin{array}{l}\text { B-CLL } \\
\text { Bladder cancer }\end{array}$ & $\begin{array}{l}\text { aHigh serum CD95 was a negative prognostic marker } \\
\text { CD95L expression (PCR) higher in cancer } \\
\text { a Serum CD95L correlated with disease progression } \\
\text { a Serum CD95 and CD95L were negative prognostic indicators } \\
\text { A correlation existed between CD95L expression (IHC) and high tumor grade and stage } \\
\text { Urine CD95 level was significantly higher in cases with recurrent disease }\end{array}$ & $\begin{array}{l}\text { Osorio et al. }{ }^{131} \\
{ }^{\mathrm{b}} \text { Muschen et al. }{ }^{132} \\
\text { Mizutani et al. }{ }^{133} \\
\text { Mizutani et al. }{ }^{134} \\
{ }^{\mathrm{b}} \text { Chopin et al. }{ }^{135} \\
\text { Yang et al. }{ }^{136}\end{array}$ \\
\hline Breast cancer & 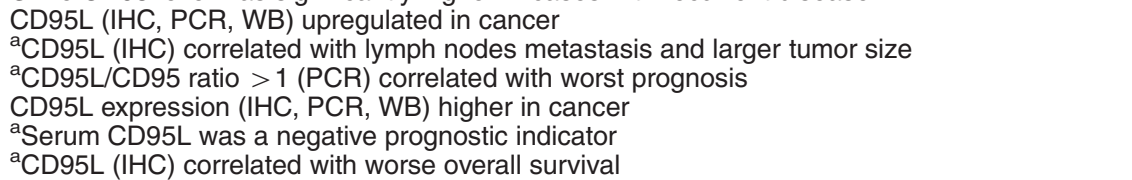 & $\begin{array}{l}{ }^{\mathrm{b}} \text { Gutierrez et al. } \\
\text { Mottolese et al. } \\
\text { Reimer et al. }{ }^{139} \\
{ }^{\mathrm{b}} \text { Mullauer et al. }{ }^{140} \\
{ }^{\mathrm{b}} \text { Bewick et al. }{ }^{141} \\
\text { Munakata et al. }{ }^{142}\end{array}$ \\
\hline Cervical cancer & $\begin{array}{l}\text { Serum levels of CD95L higher in cancer and correlating with CD95L in tumors } \\
\text { CD95L expression (IHC) higher in cancer, correlating with disease progression }\end{array}$ & $\begin{array}{l}{ }^{\mathrm{b}} \text { Song et } a l^{143} \\
{ }^{\mathrm{b}} \mathrm{Wu} \text { et } \mathrm{al} .{ }^{144}\end{array}$ \\
\hline $\begin{array}{l}\text { Cervical squamous cell } \\
\text { carcinoma }\end{array}$ & $\begin{array}{l}{ }^{a} \mathrm{CD} 95 \mathrm{~L} \text { overproduction (IHC) was more frequent in advanced-stage tumors and was inversely } \\
\text { related to survival }\end{array}$ & ${ }^{\mathrm{b}}$ Lerma et al. ${ }^{145}$ \\
\hline Colon cancer & $\begin{array}{l}\text { Metastasizing subpopulations of colorectal tumor cells express CD95L more frequently } \\
\text { (RT-PCR) than the primary carcinomas } \\
\text { A positive linear correlation was found between CD95L expression (IHC) and tumor progression } \\
\text { throughout the colorectal adenoma-carcinoma sequence } \\
\text { High CD95L (IHC) expression correlated with lymph node involvement and distant metastases } \\
\text { CD95L expression (IHC) higher in cancer, correlating with disease progression } \\
\text { Locally aggressive and metastatic human colon tumors express CD95L } \\
\text { aHigh serum CD95L levels were associated with poor survival } \\
\text { CD95L expression (IHC) correlated with disease progression } \\
\text { CD95L expression (IHC) increased during cancer progression } \\
\text { aHigh CD95L expression (IHC) was significantly correlated with disease recurrence following } \\
\text { neoadjuvant chemoradiotherapy }\end{array}$ & $\begin{array}{l}{ }^{\mathrm{b}} \text { Mann et al. }{ }^{146} \\
\text { Belucco et al. }{ }^{147} \\
{ }^{\mathrm{b}} \text { Nozoe et al. }{ }^{148} \\
{ }^{\mathrm{b}} \mathrm{Zhang} \mathrm{et} \mathrm{al.}^{149} \\
\text { Li et al. }{ }^{150} \\
\text { Hoogwater et al. }{ }^{151} \\
\text { Kykalos et al. }{ }^{152} \\
{\text { Zheng et al. }{ }^{112}}^{{ }^{b} \text { Saigusa et al. }{ }^{153}}\end{array}$ \\
\hline $\begin{array}{l}\text { Esophageal squamous cell } \\
\text { carcinoma }\end{array}$ & $\begin{array}{l}\text { CD95L expression (IHC) correlated with metastases but had no impact on survival } \\
\text { aSerum CD95L was a negative prognostic indicator } \\
\text { a Longer disease-free survival for CD95L (IHC)-negative tumors }\end{array}$ & $\begin{array}{l}\text { bShibakita et al. }{ }^{94} \\
\text { b }{ }^{154} \text { sutsumi et al. } \\
\text { Kase et al. }{ }^{97}\end{array}$ \\
\hline Gastric cancer & $\begin{array}{l}\text { Serum levels of CD95L higher in cancer } \\
\text { aCD95L-positivity (IHC) correlated with lymph node metastases and poor outcome } \\
\text { Upregulation of CD95L (IHC) correlated with the tumor progression } \\
\text { CD95L expression was significantly correlated with tumor size, invasive depth, and metastasis } \\
\text { CD95L (IHC) upregulated in cancer }\end{array}$ & $\begin{array}{l}\text { Ichikura et al. } \\
{ }^{155} \text { Nagashima et al. }{ }^{156} \\
{ }^{\mathrm{b}} \text { Osaki et al. }{ }^{157} \\
{ }^{\mathrm{b}} \text { Zheng et al. }{ }^{158} \\
{ }^{\mathrm{b}} \text { Nada et al. }{ }^{159}\end{array}$ \\
\hline Hepatocellular carcinoma & $\begin{array}{l}\text { Serum levels of CD95L higher in cancer } \\
\text { Serum levels of CD95L higher in cancer }\end{array}$ & $\begin{array}{l}\text { Tanaka et al. } \\
\text { El Bassiouny } \\
\text { et al. }\end{array}$ \\
\hline $\begin{array}{l}\text { Large granular lymphocytic } \\
\text { leukemia }\end{array}$ & Serum levels of CD95L higher in cancer & Tanaka et al. ${ }^{160}$ \\
\hline Natural killer cell lymphoma & Ascites-derived ovarian cancer cells secrete soluble CD & ${ }^{\mathrm{b}}$ Abrahams et al. ${ }^{162}$ \\
\hline Ovarian cancer & $\begin{array}{l}\text { aCD95L (IHC)-positive cases showed a less favorable prognosis than those without } \\
\text { CD95L expression } \\
\text { High CD95L expression (WB) is found in tumor-derived membrane fragments and in } \\
\text { endometrial cancer correlates with the stage of the disease } \\
\text { apatients with a high post- and pre-operative CD95L serum expression ratio (ELISA) had worse } \\
\text { prognosis to chemotherapy }\end{array}$ & $\begin{array}{l}\text { Munakata et al. }{ }^{163} \\
{ }^{\text {b}} \text { Taylor et al. }{ }^{164} \\
\text { Chaudhry et al. }{ }^{165}\end{array}$ \\
\hline $\begin{array}{l}\text { Ovarian and endometrial } \\
\text { cancer }\end{array}$ & Serum soluble CD95 and CD95L correlated with disease progression & ${ }^{\mathrm{b}}$ Bellone et al. ${ }^{166}$ \\
\hline Pancreatic cancer & $\begin{array}{l}\text { Serum levels of CD95L higher in cancer } \\
\text { CD95 expression (gene array and IHC) correlated with stemness and EMT markers and was } \\
\text { also in metastatic versus primary pancreatic ductal adenocarcinoma }\end{array}$ & $\begin{array}{l}\text { Hazar et al. }{ }^{167} \\
\text { Teodorczyk et al. }\end{array}$ \\
\hline Pediatric ALL, B-cell NHL & aHigh CD95 (IHC) associated with lymph node metastasis and worse survival & $\begin{array}{l}\text { Macher-Goeppinger } \\
\text { et al. }{ }^{168}\end{array}$ \\
\hline Renal cancer & $\begin{array}{l}\text { aHigh CD95/CD95L (IHC) neoplastic cells showed a more aggressive clinical behavior } \\
\text { aHigh CD95 (PCR) correlated with worse overall survival }\end{array}$ & $\begin{array}{l}\text { Somma et al. } \\
\text { Sejima et al. }{ }^{170}\end{array}$ \\
\hline $\begin{array}{l}\text { Oral squamous cell } \\
\text { carcinoma }\end{array}$ & ${ }^{\mathrm{a} C D} 95-$ positive cancers (IHC) had a better response to chemotherapy and outcome & Muraki et al. ${ }^{171}$ \\
\hline Testicular germ cell cancer & $\begin{array}{l}\text { CD95L expression (IHC) increased in cancer especially in patients with lymph node metastases } \\
\text { CD95L expression (PCR) higher in cancer } \\
\text { CD95L expression (IHC, PCR, WB) higher in cancer }\end{array}$ & $\begin{array}{l}{ }^{\mathrm{b}} \text { Fang et } \text { al. }^{172} \\
\text { Hara et al. }{ }^{173} \\
{ }^{\mathrm{b}} \text { Baldini et } \text { al. }{ }^{174}\end{array}$ \\
\hline Thyroid cancer & $\begin{array}{l}\text { CD95L (IHC) upregulated in cancer } \\
\text { apatients with recurrence had higher levels of soluble CD95L expression }\end{array}$ & $\begin{array}{l}\text { Rzeszutko et al. }{ }^{175} \\
\text { Owonikoko et al. }{ }^{176}\end{array}$ \\
\hline
\end{tabular}

Abbreviations: ALL, acute lymphoblastic leukemia; CLL, chronic lymphocytic leukemia; ELISA, enzyme-linked immune assay; IHC, immunohistochemistry; NHL, nonHodgkin's lymphoma; WB, western blotting

${ }^{\mathrm{a} C D} 95$ or CD95L served as prognostic marker

${ }^{\mathrm{b}}$ In these reports, upregulation of CD95L in cancer was solely discussed in the context of the CD95L counterattack model 
Table 2 Tumor-promoting activities of CD95 and CD95L in vitro and in mouse models

\begin{tabular}{|c|c|c|}
\hline Cancer type & Observation & Reference \\
\hline \multirow[t]{5}{*}{ Multiple cancers } & $\begin{array}{l}\text { Stimulation of } 22 \text { breast, ovarian, lung, colon, renal, melanoma, or glioblastoma cancer cell lines } \\
\text { through CD } 95 \text { caused them to increase in motility and invasiveness by activating NF- } \kappa \text { B and MAP } \\
\text { kinase pathways and upregulation of UPA }\end{array}$ & Barnhart et al. ${ }^{64}$ \\
\hline & $\begin{array}{l}\text { Knockdown of either CD95 or CD95L resulted in reduced growth of ovarian, liver, colon, and } \\
\text { breast cancer cell lines in vitro, and of ovarian cancer cell lines in xenografted mice }\end{array}$ & Chen et al. ${ }^{44}$ \\
\hline & $\begin{array}{l}\text { In lung cancer, GBM and hepatocellular carcinoma cell lines CD95L increased motility and cell } \\
\text { growth through binding to c-Met }\end{array}$ & Lin et al. ${ }^{177}$ \\
\hline & $\begin{array}{l}\text { Knockdown of either CD95 or CD95L resulted in induction of cell death in } 12 \text { cancer cell lines } \\
\text { representing ovarian, liver, breast, cervical, colon, renal cancer, neuroblastoma, or glioblastoma }\end{array}$ & Hadji et al. ${ }^{119}$ \\
\hline & $\begin{array}{l}\text { Stimulation of CD95 on breast, ovarian, renal, colon cancer, and glioblastoma cell lines increases } \\
\text { cancer stemness }\end{array}$ & Ceppi et al. ${ }^{115}$ \\
\hline \multirow[t]{2}{*}{ Breast cancer } & $\begin{array}{l}\text { Stimulation of CD95 on triple-negative breast cancer cells by soluble CD95L resulted in Yes/ } \\
\text { Orai1/EGFR/PI3K-mediated migration }\end{array}$ & Malleter et al. ${ }^{82}$ \\
\hline & $\begin{array}{l}\text { Blockade of CD95 signaling in } 4 \mathrm{~T} 1 \text { cancer cells markedly reduced tumor growth, inhibited tumor } \\
\text { metastasis in vivo, and prolonged survival of tumor-bearing mice }\end{array}$ & Liu et al. ${ }^{178}$ \\
\hline Colon cancer & $\begin{array}{l}\text { Expression of CD95L on colon cancer cells greatly increased their local growth and ability to } \\
\text { metastasize to the liver }\end{array}$ & Li et al. ${ }^{150}$ \\
\hline
\end{tabular}
CD95-driven liver metastasis of CD95-stimulated colon cancer cells is dependent on oncogenic Hoogwater et al. ${ }^{70}$ Kras

Radiofrequency ablation of colorectal liver metastases induced hypoxia, which caused autocrine Nijkamp et al. ${ }^{75}$ activation of CD95-promoting local invasion and accelerated metastasis outgrowth CD95 triggering resulted in an increased metastatic ability and activation of EMT in cells resistant Ametller et al. ${ }^{125}$ to oxaliplatin

CD95 stimulation induced phosphorylation of phospholipase C- $\gamma 1$ through the platelet-derived Steller et al. ${ }^{81}$ growth factor receptor- $\beta$, resulting in phosphatidylinositol $(4,5)$-bisphosphate (PIP2) hydrolysis, liberating cofilin from the plasma membrane to initiate cortical actin remodeling in turn increasing tumor cell invasion

Gastrointestinal cancer CD95 stimulation induced ERK1/2-driven EMT and motility

Hepatocellular carcinoma Neutralizing CD95L in a transgenic model of hepatocellular carcinogenesis reduced both $\quad$ Nakamoto et al. $^{179}$ inflammation and tumor formation

Mice with a point mutation in the CD95 DD expressed only on non-hematopoietic cells developed Park et al. ${ }^{180}$ spontaneous liver cancer independent of the lack of apoptosis induction through CD95 Mice with tissue-specific deletion of CD95 in hepatocytes showed a $50 \%$ reduce occurrence of Chen et al. ${ }^{44}$ DEN-induced liver cancer

Histiocytic sarcoma $\quad$ Cancer formed in the liver of mice engineered to express only soluble and lacking expression of La et $^{78}{ }^{78}$ membrane-bound CD95L

CD95 overexpressing Lewis lung carcinoma (3LL) cells grew faster in vivo in syngeneic mice Lee et al. ${ }^{68}$

Lung cancer when compared with control-transfected cells

CD95 ligation induced 3LL cells to produce the proinflammatory factor PGE2 by activating p38 Zhang et al. ${ }^{69}$ contributing to CD95 ligation-induced chemoattraction of myeloid-derived suppressor cells CD95-mediated activation of NF- $k B$ was found to contribute to the resistance of lung cancer to Bivona et al. ${ }^{79}$ a EGFR tyrosine kinase inhibitor

Melanoma Stimulation of B16 cells by exosom

Ovarian cancer increases migration to the lung Mice lacking expression of CD95 in the surface epithelial cells of the ovaries barely developed Chen et al. ${ }^{44}$ cancer in a mouse model of endometrioid ovarian cancer driven by oncogenic Kras and deletion of pten

Tissue-specific deletion of CD95 in the ovaries resulted in an increase in inflammation in the ovaries and reduced tumor development in a model of low-grade ovarian cancer driven by oncogenic Kras and deletion of pten. All outgrowing cancer cells still expressed at least one allele of wt CD95

Pancreatic cancer Stimulation of TRAF2 overexpressing cells resulted in increased invasiveness by activating $N F-\kappa B$ and $A P-1$ resulting in upregulated UPA Stimulation of CD95 on FADD knockdown cell lines mediated cell survival by recruiting calmodulin Yuan et al. $^{72}$ and Src resulting in activation of ERK

CD95 was identified as upregulated on cancer stem cells driving cell cycle progression by using Teodorczyk et al. ${ }^{83}$ Sck. Invasiveness and tumor growth could be inhibited in vivo by blocking CD95L

Thyroid cancer Stimulation of CD95 induced cell growth through ERK, NF- $k$ B, and AP-1

Mitsiades et al. ${ }^{182}$

receptor-beta mediated phospholipase $\mathrm{C}-\gamma$ activation and phosphatidylinositol (4,5)-bisphosphate hydrolysis. ${ }^{81}$ The subsequent release of cofilin from the plasma membrane and the continued suppression of LIMK1 by Kras/RAF1 together allow robust activation of the cofilin pathway. Cofilin activation was shown to be required for CD95-stimulated formation of membrane protrusions and increased tumor cell invasion. Recently, metalloproteinase-cleaved CD95L was reported to trigger a motility-inducing signaling complex formation in triple-negative breast cancer cells. ${ }^{82}$ Most recently, it was shown that CD95-mediated activation of Sck/Shc2 is indispensable for cell cycle progression of metastatic pancreatic ductal adenocarcinoma (PDAC) ${ }^{83}$ These data suggest that CD95 is connected to a myriad of prosurvival and migratory signaling pathways.

We recently tested the relevance of these nonapoptotic functions of CD95 and CD95L for cancer cells. We knocked down either CD95 or CD95L in numerous cancer cell lines 
using multiple small interfering RNA (siRNAs) and shRNAs. This resulted in a profound reduction in growth of the cancer cells. ${ }^{44}$ In addition, we generated tissue-specific knockout mice lacking CD95 expression in the liver or on the surface epithelial cells of the ovaries. Using appropriate tumor mouse models, we found a severe reduction in liver cancer in mice lacking CD95 in hepatocytes (diethylnitrosamine injection model), and mice lacking CD95 in the ovaries barely developed cancer at all (using the $\mathrm{Kras}^{\mathrm{D} 12 \mathrm{G}} /$ pten-Iendometrioid ovarian cancer mode ${ }^{84}$ ). Finally, it was shown that mice that only express soluble but not mCD95L suffer from large histiocytic sarcomas in the liver, ${ }^{78}$ likely owing to a lack of apoptosis induction and a tumorigenic activity of CD95L.

A number of studies reported CD95 as a positive prognostic marker for cancer. ${ }^{85-99}$ This is likely owing to the fact that CD95 is often downregulated during tumor progression because cancer cells need to lower the risk of undergoing apoptosis while benefiting from CD95's tumorigenic activities. Occasionally, CD95L was also described as a positive prognostic marker for cancer. ${ }^{86,100,101}$ However, the vast majority of reports have shown that disease progression is associated with progressively increased expression of CD95L and sometimes also CD95, and expression of both CD95 and especially of CD95L in most cases act as negative prognostic markers for many cancers (Table 1). In summary, most studies suggest that CD95 and/or CD95L expression promotes tumor growth and favors the establishment of tumor metastases.

Maintenance of CSCs by CD95 and CD95L. The cancer stem cell (CSC) model is an attractive hypothesis that translates properties of normal stem cells into the cancer field, and explains some of the most lethal features of cancers. The CSC model proposes that the cells within a tumor are hierarchically organized, and it predicts the existence of a subpopulation of cells with high tumorigenicity that are able to both self-renew and to generate differentiated cells (non-CSCs). ${ }^{102,103}$ One of the most malignant features of cancer is the appearance of relapses, sometimes years after radiotherapy or chemotherapeutical intervention, and this has been related to the occurrence of cells with the CSC phenotype. ${ }^{104}$ Therefore, elucidating the mechanisms of CSC maintenance is important for understanding tumor cell persistence and relapse, and may enable specific targeting of CSCs, a promising therapeutic strategy to stably eradicate cancer. $^{105,106}$

CD95 and CD95 signaling have been connected to normal stem cells. ${ }^{45,107}$ CD95 was, in fact, previously identified as a candidate stem cell marker (along with well-established stem cell markers such as Lin28, Oct4, Nanog, and Sox2, among others) in a serial analysis of gene expression profiling of human embryonic stem cells. ${ }^{108}$ Functional evidence of a prosurvival function of CD95 and CD95L signaling in normal stem cells came from experiments that showed that the stimulation of CD95 signaling in neuronal stem cells did not cause death, but rather increased the survival of neuronal stem cells via a Src/PI3K/AKT/mTOR signaling pathway, while, conversely, deletion of CD95 resulted in reduced neurogenesis. ${ }^{107}$ Because normal stem cells are often the origin of CSCs, these data were suggestive that CD95 may also have a nonapoptotic function in CSCs.
In the context of cancer, CD95 expression and CD95 signaling have been connected with the differentiation of cells. We reported this based on an analysis of the $\mathrm{NCl}-60$ panel of cancer cells, which could be divided in two super-clusters with distinct differentiation stages that responded differently to CD95 stimulation. ${ }^{109}$ Interestingly, expression of CD95 inversely correlated with expression of the stem cell-inhibiting members of the let-7 family of micro RNAs (miRNAs), and stimulation of CD95 caused a reduction in let-7 expression. ${ }^{110}$ Moreover, and related to this, CD95 has been shown to be capable of inducing the epithelial-to-mesenchymal transition (EMT) differentiation program in gastrointestinal cancer ${ }^{111,112}$ (Figure 2-5, EMT and CSC maintenance). In these studies, the authors demonstrated that CD95 signaling inactivates GSK3 $\beta$ by $E R K /$ mitogen-activated protein kinase signaling resulting in increased nuclear import and interaction between AP-1 and NFAT4. This increases their transcriptional activity leading to nuclear accumulation of Snail and $\beta$-catenin and miR-23a expression, and subsequently, downregulation of E-cadherin and upregulation of MMP9 and vimentin in vivo and in vitro. ${ }^{111,113}$ EMT has been previously connected with the generation of cells with the properties of CSCs. ${ }^{114}$

We recently demonstrated that CD95 is required for the survival of CSCs and allows new CSCs to emerge ${ }^{115}$ (Figure 2-5, EMT and CSC maintenance). Stimulation of CD95 on multiple tumor cells induced a conversion from nonCSCs to CSCs. This reprogramming activity of CD95 was independent of its apoptosis-inducing function, as it was not blocked by the pan-caspase inhibitor zVAD-fmk; rather, it represents a mechanism of retro-differentiation. Strikingly, CSCs from highly apoptosis-sensitive HeyA8 ovarian cancer cells enriched in tumor spheres were found to be almost completely resistant to CD95-mediated apoptosis. For breast cancer, we could connect this novel function of CD95/CD95L to the activity of miR-200, a miRNA previously linked to both EMT and CSCs. ${ }^{114,116,117}$ miR-200c expression increased the sensitivity of cancer cells to CD95-mediated apoptosis. ${ }^{118}$ Stimulation of CD95 not only increased the number of cancer cells with stem cell traits but also prevented differentiation of CSCs, suggesting that CD95 expression on cancer cells maintains the CSC pool. ${ }^{115}$ A connection between CD95 and CSCs was recently also reported for PDAC. ${ }^{83}$ CD95 expression strongly correlated with stemness and EMT markers and blocking CD95L reduced tumor growth and metastasis in vivo.

Death induced by CD95R/L elimination. Following up on our finding that CD95 contributes to the proliferation of cancer cells, ${ }^{44}$ we recently reported that the elimination of either CD95 or CD95L kills cancer cells (in vitro and in vivo) in a process we termed DICE (death induced by CD95 or CD95L elimination) ${ }^{119}$ (Figure 2-6, DICE). This activity of CD95 as a survival factor seems to be mostly relevant to cancer cells, as none of the normal tissues during embryonic development in either CD95 or CD95L knockout mice showed a growth defect or signs of cell death. ${ }^{6-8}$ Consistently, we found increased sensitivity to DICE in ovarian surface epithelial cells after they were immortalized by expression of hTERT. ${ }^{119}$

We found that all cancer cells tested ( 40 lines tested to date) substantially die by DICE when either CD95 or CD95L is knocked down. We used 15 different non-overlapping si/shRNAs 
against either of the two genes, and all induce DICE. We generated Tet-inducible vectors (pTIP) to express the shRNAs. They kill all cancer cells when doxycycline is added. In two ovarian cancer mouse models and one mouse model of chemically induced liver cancer, tumor formation was severely reduced in the absence of CD95. ${ }^{44,119}$ In fact, a reanalysis of the tumor samples revealed that not a single cancer cell could be detected in any of the models that had deleted both alleles of CD95. ${ }^{119}$ We reported that DICE has the following properties: $^{119}$

1. DICE represents a necrotic form of mitotic catastrophe with signs of apoptosis, ${ }^{119}$ autophagy, and senescence (unpublished data).

2. DICE is characterized by cell swelling and production of reactive oxygen species followed by DNA damage and activation of caspase-2, resulting in mitochondrial outer membrane permeabilization. Cells eventually die by a RIP1/mixed lineage-like kinase-independent mechanism. Although multiple cell death pathways are activated, RIPKdependent necroptosis does not seem to be critical, suggesting that DICE induction may not cause inflammation.

3. DICE could not be inhibited by any of 1200 tested drugs or by knockdown of any single gene in a genome-wide shRNA screen, ${ }^{119}$ suggesting that it is a robust cell death mechanism that is difficult to block.

We recently postulated that DICE is a fail-safe mechanism, a dead man's switch, that prevents the survival of cancer cells that are devoid of CD95, and, hence, would not be eliminated by the immune system through CD95L/CD95-mediated apoptosis. ${ }^{120}$ Thus, DICE is a naturally occurring antitumor defense mechanism. The observation that in tumor cells both alleles of CD95 are rarely if ever mutated or deleted (reviewed in Peter et al. $^{41}$ ) is consistent with this interpretation. Our recent data show that all cancer cells autonomously produce a small amount of CD95L, suggesting that the loss of either CD95 or CD95L induces DICE, which is consistent with our observation that cancer cells never delete both alleles of CD95. ${ }^{119}$

Our study of CSCs revealed a crucial role for CD95 signaling in regulating cancer differentiation, and indicated that the two death mechanisms, DICE and canonical CD95-mediated apoptosis, have opposing roles in eliminating CSCs and non-CSCs. Conversion of non-CSCs to CSCs resulted in a loss of sensitivity to CD95-mediated apoptosis and a concomitant increase in the sensitivity of the cells to DICE. ${ }^{115}$ In fact, we found that DICE preferentially targets CSCs. ${ }^{115}$ When DICE was induced in multiple cancer cell lines or primary breast cancer cells, they became depleted of CSCs. Cells lost typical CSC surface markers, formed spheres less efficiently, and lost expression of endogenous CSC markers while becoming enriched in the stem cell-controlling miRNA miR-200c.

\section{Targeting CD95L to Kill Cancer Cells}

The data summarized above suggest that CD95 and CD95L act as oncogenes once cancer cells have become resistant to the apoptosis-inducing activity of CD95. The data further seem to suggest that the reason that cancer cells die after removal of either CD95 or CD95L is that they are addicted to their oncogenic activities. However, for the following reasons, we would argue that DICE is not the result of a broken oncogene addiction: (1) CD95 and CD95L intrinsically have tumor-suppressive activities in the context of the immune system (see above). (2) Elimination of CD95 or CD95L can kill any cancer cell we have tested, not just cells that overexpress CD95 or CD95L. In fact, CD95L expression in most cancer cells is barely detectable, yet elimination of CD95L induces DICE more effectively in cells that express less CD95L, perhaps because CD95L becomes rate limiting more easily. CD95 and CD95L may be the first identified tumorsuppressive genes that are so important that their loss (which could occur as neoplastically transformed cells continue to acquire mutations) triggers a fail-safe program to kill such cells. An interesting aspect of this model is that, by definition, the DICE mechanism has not been triggered in any cancer cell found in a cancer patient, the implication being that cancer cells do not become resistant to DICE, but they become resistant to apoptosis and may evade DICE by retaining expression of CD95 and CD95L.

Because neither CD95 nor CD95L knockout mice are known to exhibit any defects in the proliferation of any tissue and exhibit no defects in stem cell compartments, ${ }^{6-8}$ it is possible that CD95 or CD95L could be safely targeted for therapeutic purposes. Targeting CD95L systemically would block all the tumorigenic activities summarized in Figure 2.

\section{Inducing DICE in Combination with Standard Chemotherapy}

Although induction of DICE alone may be effective in killing cancer cells, the combination of induction of DICE with existing therapies and concepts may be beneficial in improving outcomes of cancer therapy. During our analysis of the role of CD95 in CSCs, we identified a strong synergy between DICE and CD95-mediated apoptosis in eradicating cancer. ${ }^{115}$ The synergy is a direct consequence of the differential sensitivities of CSCs and non-CSCs to the two death mechanisms. Thus, a therapy that combined the two death mechanisms could be beneficial to cancer treatment by targeting two differentiation stages of cancer development. It has been reported multiple times that many forms of chemotherapy act by inducing, at least in part, apoptosis in cancer cells, sometimes through upregulation of CD95L. ${ }^{121,122}$ It is also established that cancer patients who become refractory to therapy have an increased CSC population, ${ }^{123,124}$ which we recently showed to be more sensitive to DICE than non-CSCs. Thus, a combination of lowdose chemotherapy coupled with targeting CD95 may be beneficial as it should target both non-CSCs and CSCs. Targeting of CD95L could also be a beneficial addition to chemotherapy because chemotherapy-induced upregulation of CD95L has been suggested to not only drive cancer cells into apoptosis but to promote growth of drug resistant tumor cells. $^{125}$ 


\section{Inducing DICE in Combination with Inhibition of Immune Checkpoint Receptors}

An effective mechanism to treat certain cancers involves the mobilization of the immune system. Cancer cells have found ways to suppress the antitumor response mounted by the immune system, but recent successes of therapies that are aimed toward de-repressing the tumor-imposed block on the immune system are evidence of the power of these mechanisms. Anti-PDL1 and anti-PD-1 clinical trials have shown promising effects in melanoma, renal, colorectal, and non-small cell lung cancer patients, and, for the first time ever in the development of immune therapy, a sizeable fraction of patients were observed who had a durable response that increased their life span. ${ }^{126-129}$ Based on these early data, one can predict that success in cancer therapy will come from harnessing natural mechanisms that control cancer in general (e.g., an antitumor immune response) rather than from cancer-specific strategies. Empowering the immune system by targeting immune check point signaling and simultaneously attacking the cancer cells by inducing DICE may represent a viable combination of therapies both of which activate preexisting antitumor mechanisms.

\section{Conclusions and Perspectives}

Using CD95L for cancer therapy was never a viable option to treat cancer because of its devastating effects on the liver. Accumulating evidence now suggests that cancer cells can never lose CD95 or CD95L and if they do, they die. This provides an opportunity to use targeting either CD95 or CD95L to treat cancer. However, there are many open questions that need to be addressed first. Although excess of CD95L secreted by tumor cells may drive EMT and stemness and render tumor cells more motile and invasive, it is not clear whether targeting this secreted protein will be enough to block the tumor-promoting activities of CD95 and CD95L. In our hands, blocking the activity of extracellular CD95L has had no effect on cell viability. ${ }^{119}$ In addition, recent data suggest that both CD95L and CD95 are located in intracellular stores, ${ }^{119}$ hence they may exert their activity to protect cancer cells from DICE from within the cell. It may therefore be necessary to target the intracellular proteins or the mRNAs of CD95 and CD95L. This will require development of more efficient ways to deliver siRNAs to cells or the development of new technologies to eliminate genes from cells all together (i.e., using the clustered regularly interspaced short palindromic repeats (CRISPR)/Cas9 system).

\section{Conflict of Interest}

The authors declare no conflict of interest.

Acknowledgements. SB and WP are supported in part by $\mathrm{NIH} / \mathrm{NCl}$ training grant T32CA09560. PC is supported by a DOD postdoctoral fellowship W81XWH-131-0301. MEP is supported by R01 CA149356.

1. Nagata S. Apoptosis by death factor. Cell 1997; 88: 355-365.

2. Krammer PH. CD95's deadly mission in the immune system. Nature 2000; 407: 789-795.

3. Peter ME, Barnhart BC, Algeciras-Schimnich A. The Cytokine Handbook: CD95L/FasL and its receptor CD95 (APO-1/Fas). Cytokine Handb 2003; 2: 885-911.
4. Watanabe-Fukunaga R, Brannan $\mathrm{Cl}$, Copeland NG, Jenkins NA, Nagata S. Lymphoproliferation disorder in mice explained by defects in Fas antigen that mediates apoptosis. Nature 1992; 356: 314-317.

5. Takahashi T, Tanaka M, Brannan Cl, Jenkins NA, Copeland NG, Suda T et al. Generalized lymphoproliferative disease in mice, caused by a point mutation in the Fas ligand. Cell 1994; 76: 969-976.

6. Adachi M, Suematsu S, Kondo T, Ogasawara J, Tanaka T, Yoshida N et al. Targeted mutation in the Fas gene causes hyperplasia in peripheral lymphoid organs and liver. Nat Genet 1995; 11: 294-300.

7. Karray S, Kress C, Cuvellier S, Hue-Beauvais C, Damotte D, Babinet C et al. Complete loss of Fas ligand gene causes massive lymphoproliferation and early death, indicating a residual activity of gld allele. J Immunol 2004; 172: 2118-2125.

8. Senju S, Negishi I, Motoyama N, Wang F, Nakayama K, Lucas PJ et al. Functional significance of the Fas molecule in naive lymphocytes. Int Immunol 1996; 8: 423-431.

9. Kimura M, Matsuzawa A. Autoimmunity in mice bearing lprcg: a novel mutant gene. Int Rev Immunol 1994; 11: 193-210.

10. Bidere N, Su HC, Lenardo MJ. Genetic disorders of programmed cell death in the immune system. Annu Rev Immunol 2006; 24: 321-352.

11. Siegel RM, Frederiksen JK, Zacharias DA, Chan FK, Johnson M, Lynch D et al. Fas preassociation required for apoptosis signaling and dominant inhibition by pathogenic mutations. Science 2000; 288: 2354-2357.

12. Algeciras-Schimnich A, Shen L, Barnhart BC, Murmann AE, Burkhardt JK, Peter ME. Molecular ordering of the initial signaling events of CD95. Mol Cell Biol 2002; 22: 207-220.

13. Peter ME, Krammer PH. The CD95(APO-1/Fas) DISC and beyond. Cell Death Differ 2003; 10: $26-35$.

14. Medema JP, Scaffidi C, Kischkel FC, Shevchenko A, Mann M, Krammer PH et al. FLICE is activated by association with the CD95 death-inducing signaling complex (DISC). EMBO J 1997; 16: 2794-2804.

15. Kagi D, Ledermann B, Burki K, Seiler P, Odermatt B, Olsen KJ et al. Cytotoxicity mediated by $T$ cells and natural killer cells is greatly impaired in perforin-deficient mice. Nature 1994; 369: 31-37.

16. Braun MY, Lowin B, French L, Acha-Orbea H, Tschopp J. Cytotoxic T cells deficient in both functional fas ligand and perforin show residual cytolytic activity yet lose their capacity to induce lethal acute graft-versus-host disease. J Exp Med 1996; 183: 657-661.

17. Winter $\mathrm{H}, \mathrm{Hu} \mathrm{HM}$, Urba WJ, Fox BA. Tumor regression after adoptive transfer of effector $\mathrm{T}$ cells is independent of perforin or Fas ligand (APO-1L/CD95L). J Immunol 1999; 163 : 4462-4472.

18. Qin Z, Schwartzkopff J, Pradera F, Kammertoens T, Seliger B, Pircher H et al. A critical requirement of interferon gamma-mediated angiostasis for tumor rejection by $\mathrm{CD} 8+\mathrm{T}$ cells. Cancer Res 2003; 63: 4095-4100.

19. Bohm W, Thoma S, Leithauser F, Moller P, Schirmbeck R, Reimann J. T cell-mediated, IFN-gamma-facilitated rejection of murine B16 melanomas. J Immunol 1998; 161 897-908.

20. Wigginton JM, Gruys E, Geiselhart L, Subleski J, Komschlies KL, Park JW et al. IFNgamma and Fas/FasL are required for the antitumor and antiangiogenic effects of IL-12/ pulse IL-2 therapy. J Clin Invest 2001; 108: 51-62.

21. Kowalczyk DW, Wlazlo AP, Giles-Davis W, Kammer AR, Mukhopadhyay S, Ertl HC. Vaccine-induced CD8+ T cells eliminate tumors by a two-staged attack. Cancer Gene Ther 2003; 10: 870-878.

22. Barth Jr RJ, Mule JJ, Spiess PJ, Rosenberg SA. Interferon gamma and tumor necrosis factor have a role in tumor regressions mediated by murine CD8+ tumor-infiltrating lymphocytes. J Exp Med 1991; 173: 647-658.

23. Prevost-Blondel A, Roth E, Rosenthal FM, Pircher H. Crucial role of TNF-alpha in CD8 T cell-mediated elimination of 3LL-A9 Lewis lung carcinoma cells in vivo. J Immunol 2000; 164: 3645-3651.

24. Lowin B, Hahne M, Mattmann C, Tschopp J. Cytolytic T-cell cytotoxicity is mediated through perforin and Fas lytic pathways. Nature 1994; 370: 650-652.

25. Kagi D, Vignaux F, Ledermann B, Burki K, Depraetere V, Nagata S et al. Fas and perforin pathways as major mechanisms of T cell-mediated cytotoxicity. Science 1994; 265 : 528-530.

26. Kojima H, Shinohara N, Hanaoka S, Someya-Shirota Y, Takagaki Y, Ohno H et al. Two distinct pathways of specific killing revealed by perforin mutant cytotoxic $\mathrm{T}$ lymphocytes. Immunity 1994; 1: 357-364.

27. Rouvier E, Luciani MF, Golstein P. Fas involvement in $\mathrm{Ca}(2+)$-independent $\mathrm{T}$ cell-mediated cytotoxicity. J Exp Med 1993; 177: 195-200.

28. Stalder T, Hahn S, Erb P. Fas antigen is the major target molecule for CD4+ T cellmediated cytotoxicity. J Immunol 1994; 152: 1127-1133.

29. Ju ST, Cui H, Panka DJ, Ettinger R, Marshak-Rothstein A. Participation of target Fas protein in apoptosis pathway induced by CD4+ Th1 and CD8+ cytotoxic T cells. Proc Natl Acad Sci USA 1994; 91: 4185-4189.

30. Holler N, Zaru R, Micheau O, Thome M, Attinger A, Valitutti S et al. Fas triggers an alternative, caspase-8-independent cell death pathway using the kinase RIP as effector molecule. Nat Immunol 2000; 1: 489-495.

31. Karl I, Jossberger-Werner M, Schmidt N, Horn S, Goebeler M, Leverkus M et al. TRAF2 inhibits TRAIL- and CD95L-induced apoptosis and necroptosis. Cell Death Dis 2014; 5: e1444. 
32. Algeciras-Schimnich A, Pietras EM, Barnhart BC, Legembre P, Vijayan S, Holbeck SL et al. Two CD95 tumor classes with different sensitivities to antitumor drugs. Proc Natl Acad Sci USA 2003; 100: 11445-11450.

33. Ivanov VN, Lopez Bergami P, Maulit G, Sato TA, Sassoon D, Ronai Z. FAP-1 association with Fas (Apo-1) inhibits Fas expression on the cell surface. Mol Cell Biol 2003; 23 : 3623-3635.

34. Ivanov VN, Ronai Z, Hei TK. Opposite roles of FAP-1 and dynamin in the regulation of Fas (CD95) translocation to the cell surface and susceptibility to Fas ligand-mediated apoptosis. J Biol Chem 2006; 281: 1840-1852.

35. Irmler M, Thome M, Hahne M, Schneider P, Hofmann K, Steiner V et al. Inhibition of death receptor signals by cellular FLIP. Nature 1997; 388: 190-195.

36. Tourneur L, Mistou S, Michiels FM, Devauchelle V, Renia L, Feunteun J et al. Loss of FADD protein expression results in a biased Fas-signaling pathway and correlates with the development of tumoral status in thyroid follicular cells. Oncogene 2003; 22 2795-2804

37. Fulda S, Kufer MU, Meyer E, van Valen F, Dockhorn-Dworniczak B, Debatin KM. Sensitization for death receptor- or drug-induced apoptosis by re-expression of caspase-8 through demethylation or gene transfer. Oncogene 2001; 20: 5865-5877.

38. Teitz T, Wei T, Valentine MB, Vanin EF, Grenet J, Valentine VA et al. Caspase 8 is deleted or silenced preferentially in childhood neuroblastomas with amplification of MYCN. Nat Med 2000; 6: 529-535.

39. Igney FH, Krammer PH. Death and anti-death: tumour resistance to apoptosis. Nat Rev Cancer 2002; 2: 277-288.

40. Peter ME, Budd RC, Desbarats J, Hedrick SM, Hueber AO, Newell MK et al. The CD95 receptor: apoptosis revisited. Cell 2007; 129: 447-450.

41. Peter ME, Legembre P, Barnhart BC. Does CD95 have tumor promoting activities? Biochim Biophys Acta 2005; 1755: 25-36.

42. Martin-Villalba A, Llorens-Bobadilla E, Wollny D. CD95 in cancer: tool or target? Trends Mol Med 2013; 19: 329-335.

43. Wajant H, Pfizenmaier K, Scheurich P. Non-apoptotic Fas signaling. Cytokine Growth Factor Rev 2003; 14: 53-66.

44. Chen L, Park SM, Tumanov AV, Hau A, Sawada K, Feig C et al. CD95 promotes tumour growth. Nature 2010; 465: 492-496.

45. Desbarats J, Newell MK. Fas engagement accelerates liver regeneration after partial hepatectomy. Nat Med 2000; 6: 920-923.

46. Jarad G, Wang B, Khan S, DeVore J, Miao H, Wu K et al. Fas activation induces renal tubular epithelial cell beta 8 integrin expression and function in the absence of apoptosis. J Biol Chem 2002; 277: 47826-47833.

47. Reinehr R, Sommerfeld A, Haussinger D. CD95 ligand is a proliferative and antiapoptotic signal in quiescent hepatic stellate cells. Gastroenterol 2008; 134 1494-1506.

48. Desbarats J, Birge RB, Mimouni-Rongy M, Weinstein DE, Palerme JS, Newell MK. Fas engagement induces neurite growth through ERK activation and p35 upregulation. Nat Cell Biol 2003; 5: 118-125

49. Zuliani C, Kleber S, Klussmann S, Wenger T, Kenzelmann M, Schreglmann N et al. Control of neuronal branching by the death receptor CD95 (Fas/Apo-1). Cell Death Differ 2006; 13: $31-40$.

50. Nagata S. Fas ligand-induced apoptosis. Annu Rev Genet 1999; 33: 29-55

51. Strasser A, Jost PJ, Nagata S. The many roles of FAS receptor signaling in the immune system. Immunity 2009; 30: 180-192.

52. Ogasawara J, Watanabe-Fukunaga R, Adachi M, Matsuzawa A, Kasugai T, Kitamura $Y$ et al. Lethal effect of the anti-Fas antibody in mice. Nature 1993; 364: 806-809.

53. Igney $\mathrm{FH}$, Behrens $\mathrm{CK}$, Krammer $\mathrm{PH}$. Tumor counterattack-concept and reality. Eur J Immunol 2000; 30: 725-731.

54. Chappell DB, Restifo NP. T cell-tumor cell: a fatal interaction? Cancer Immunol Immunother 1998; 47: 65-71

55. O'Connell J, O'Sullivan GC, Collins JK, Shanahan F. The Fas counterattack: Fas-mediated T cell killing by colon cancer cells expressing Fas ligand. J Exp Med 1996; 184: 1075-1082.

56. Igney FH, Krammer PH. Tumor counterattack: fact or fiction? Cancer Immunol Immunother 2005; 54: 1127-1136.

57. Yu JS, Lee PK, Ehtesham M, Samoto K, Black KL, Wheeler CJ. Intratumoral T cell subset ratios and Fas ligand expression on brain tumor endothelium. J Neurooncol 2003; 64 $55-61$.

58. Bajou K, Peng H, Laug WE, Maillard C, Noel A, Foidart JM et al. Plasminogen activator inhibitor-1 protects endothelial cells from FasL-mediated apoptosis. Cancer Cell 2008; 14 324-334.

59. Motz GT, Santoro SP, Wang LP, Garrabrant T, Lastra RR, Hagemann IS et al. Tumor endothelium FasL establishes a selective immune barrier promoting tolerance in tumors. Nat Med 2014; 20: 607-615.

60. Alderson MR, Armitage RJ, Maraskovsky E, Tough TW, Roux E, Schooley K et al. Fas transduces activation signals in normal human T lymphocytes. J Exp Med 1993; 178 : 2231-2235.

61. Kennedy NJ, Kataoka T, Tschopp J, Budd RC. Caspase activation is required for T cell proliferation. J Exp Med 1999; 190: 1891-1896.

62. Alam A, Cohen LY, Aouad S, Sekaly RP. Early activation of caspases during T lymphocyte stimulation results in selective substrate cleavage in nonapoptotic cells. J Exp Med 1999; 190: $1879-1890$
63. Ichikawa K, Yoshida-Kato H, Ohtsuki M, Ohsumi J, Yamaguchi J, Takahashi S et al. A novel murine anti-human Fas mAb which mitigates lymphadenopathy without hepatotoxicity. Int Immunol 2000; 12: 555-562.

64. Barnhart BC, Legembre P, Pietras E, Bubici C, Franzoso G, Peter ME. CD95 ligand induces motility and invasiveness of apoptosis-resistant tumor cells. EMBO J 2004; 23: 3175-3185.

65. Legembre P, Barnhart BC, Zheng L, Vijayan S, Straus SE, Puck J et al. Induction of apoptosis and activation of NF-kappaB by $\mathrm{CD} 95$ require different signalling thresholds. EMBO Rep 2004; 5: 1084-1089.

66. Legembre P, Barnhart BC, Peter ME. The Relevance of NF-kappaB for CD95 Signaling in Tumor Cells. Cell Cycle 2004; 3: 1235-1239.

67. Legembre P, Schickel R, Barnhart BC, Peter ME. Identification of SNF1/AMP Kinaserelated Kinase as an NF-\{kappa\}B-regulated Anti-apoptotic Kinase Involved in CD95induced Motility and Invasiveness. J Biol Chem 2004; 279: 46742-46747.

68. Lee JK, Sayers TJ, Back TC, Wigginton JM, Wiltrout RH. Lack of FasL-mediated killing leads to in vivo tumor promotion in mouse Lewis lung cancer. Apoptosis 2003; 8: 151-160.

69. Zhang Y, Liu Q, Zhang M, Yu Y, Liu X, Cao X. Fas signal promotes lung cancer growth by recruiting myeloid-derived suppressor cells via cancer cell-derived PGE2. J Immunol 2009; 182: $3801-3808$

70. Hoogwater FJ, Nijkamp MW, Smakman N, Steller EJ, Emmink BL, Westendorp BF et al. Oncogenic K-Ras turns death receptors into metastasis-promoting receptors in human and mouse colorectal cancer cells. Gastroenterol 2010; 138: 2357-2367.

71. Park SM, Chen L, Zhang M, Ashton-Rickardt P, Turner JR, Peter ME. CD95 is cytoprotective for intestinal epithelial cells in colitis. Inflamm Bowel Dis 2010; 16: 1063-1070.

72. Yuan K, Jing G, Chen J, Liu H, Zhang K, Li Y et al. Calmodulin mediates Fas-induced FADD-independent survival signaling in pancreatic cancer cells via activation of Srcextracellular signal-regulated kinase (ERK). J Biol Chem 2011; 286: 24776-24784.

73. Trauzold A, Roder C, Sipos B, Karsten K, Arlt A, Jiang P et al. CD95 and TRAF2 promote invasiveness of pancreatic cancer cells. FASEB J 2005; 19: 620-622.

74. Kleber S, Sancho-Martinez I, Wiestler B, Beisel A, Gieffers C, Hill O et al. Yes and PI3K Bind CD95 to Signal Invasion of Glioblastoma. Cancer Cell 2008; 13: 235-248.

75. Nijkamp MW, Hoogwater FJ, Steller EJ, Westendorp BF, van der Meulen MW, Rinkes IH et al. CD95 is a key mediator of invasion and accelerated outgrowth of mouse colorectal liver metastases following radiofrequency ablation. J Hepatol 2010; 53: 1069-1077.

76. Schneider $\mathrm{P}$, Holler N, Bodmer JL, Hahne M, Frei K, Fontana A et al. Conversion of membrane-bound Fas(CD95) ligand to its soluble form is associated with downregulation of its proapoptotic activity and loss of liver toxicity. J Exp Med 1998; 187: 1205-1213.

77. Tanaka M, Itai T, Adachi M, Nagata S. Downregulation of Fas ligand by shedding. Nat Med 1998; 4: 31-36.

78. La OR, Tai L, Lee L, Kruse EA, Grabow S, Fairlie WD et al. Membrane-bound Fas ligand only is essential for Fas-induced apoptosis. Nature 2009; 461: 659-663.

79. Bivona TG, Hieronymus H, Parker J, Chang K, Taron M, Rosell R et al. FAS and NF-kappaB signalling modulate dependence of lung cancers on mutant EGFR. Nature 2011; 471: 523-526.

80. Tauzin S, Chaigne-Delalande B, Selva E, Khadra N, Daburon S, Contin-Bordes C et al. The naturally processed CD95L elicits a c-yes/calcium/PI3K-driven cell migration pathway. PLoS Biol 2011; 9: e1001090.

81. Steller EJ, Ritsma L, Raats DA, Hoogwater FJ, Emmink BL, Govaert KM et al. The death receptor CD95 activates the cofilin pathway to stimulate tumour cell invasion. EMBO Rep 2011; 12: 931-937.

82. Malleter M, Tauzin S, Bessede A, Castellano R, Goubard A, Godey F et al. CD95L cell surface cleavage triggers a prometastatic signaling pathway in triple-negative breast cancer. Cancer Res 2013; 73: 6711-6721.

83. Teodorczyk M, Kleber S, Wollny D, Sefrin JP, Aykut B, Mateos A et al. CD95 promotes metastatic spread via Sck in pancreatic ductal adenocarcinoma. Cell Death Differ 2015; e-pub ahead of print 23 January 2015; doi:10.1038/cdd.2014.217.

84. Dinulescu DM, Ince TA, Quade BJ, Shafer SA, Crowley D, Jacks T. Role of K-ras and Pten in the development of mouse models of endometriosis and endometrioid ovarian cancer. Nat Med 2005; 11: 63-70.

85. Chan KW, Lee PY, Lam AK, Law S, Wong J, Srivastava G. Clinical relevance of Fas expression in oesophageal squamous cell carcinoma. J Clin Pathol 2006; 59: 101-104.

86. Kojima Y, Tsurumi H, Goto N, Shimizu M, Kasahara S, Yamada T et al. Fas and Fas ligand expression on germinal center type-diffuse large B-cell lymphoma is associated with the clinical outcome. Eur J Haematol 2006; 76: 465-472.

87. Yamana K, Bilim V, Hara N, Kasahara T, Itoi T, Maruyama R et al. Prognostic impact of FAS/CD95/APO-1 in urothelial cancers: decreased expression of Fas is associated with disease progression. Br J Cancer 2005; 93: 544-551.

88. Eser B, Sari I, Canoz O, Altuntas F, Cakmak E, Ozturk A et al. Prognostic significance of Fas (CD95/APO-1) positivity in patients with primary nodal diffuse large B-cell lymphoma. Am J Hematol 2006; 81: 307-314.

89. Chatzitolios A, Venizelos I, Tripsiannis G, Anastassopoulos G, Papadopoulos N. Prognostic significance of CD95, P53, and BCL2 expression in extranodal non-Hodgkin's lymphoma. Ann Hematol 2010; 89: 889-896.

90. de Carvalho-Neto PB, dos Santos M, de Carvalho MB, Mercante AM, dos Santos VP, Severino $\mathrm{P}$ et al. FAS/FASL expression profile as a prognostic marker in squamous cell carcinoma of the oral cavity. PLoS One 2013; 8: e69024. 
91. Strater J, Hinz U, Hasel C, Bhanot U, Mechtersheimer G, Lehnert T et al. Impaired CD95 expression predisposes for recurrence in curatively resected colon carcinoma: clinical evidence for immunoselection and CD95L mediated control of minimal residual disease. Gut 2005; 54: 661-665.

92. Asensio C, Zapata A, Garcia-Ahijado J, Gil B, Salvadores P, Schneider J. Fas expression is associated with a better prognosis in laryngeal squamous cell carcinoma. Anticancer Res 2007; 27: 4083-4086.

93. Koomagi R, Volm M. Expression of Fas (CD95/APO-1) and Fas ligand in lung cancer, its prognostic and predictive relevance. Int J Cancer 1999; 84: 239-243.

94. Shibakita M, Tachibana M, Dhar DK, Kotoh T, Kinugasa S, Kubota H et al. Prognostic significance of Fas and Fas ligand expressions in human esophageal cancer. Clin Cancer Res 1999; 5: 2464-2469.

95. Baryshnikov A, Polosukhina ER, Tupitsin NN, Gavrikova NV, Andreeva L, Zabotina TN et al. CD95 (FAS/APO-1) antigen is a new prognostic marker of blast cells of acute lymphoblastic leukaemia patients. Adv Exp Med Biol 1999; 457: 251-258.

96. Uramoto H, Osaki T, Inoue M, Taga S, Takenoyama M, Hanagiri T et al. Fas expression in non-small cell lung cancer: its prognostic effect in completely resected stage III patients. Eur J Cancer 1999; 35: 1462-1465.

97. Kase S, Osaki M, Adachi $\mathrm{H}$, Kaibara $\mathrm{N}$, Ito $\mathrm{H}$. Expression of Fas and Fas ligand in esophageal tissue mucosa and carcinomas. Int $J$ Oncol 2002; 20: 291-297.

98. Volm M, Koomagi R, Mattern J, Efferth T. Expression profile of genes in non-small cell lung carcinomas from long-term surviving patients. Clin Cancer Res 2002; 8 : 1843-1848.

99. Bernstorff WV, Glickman JN, Odze RD, Farraye FA, Joo HG, Goedegebuure PS et al. Fas (CD95/APO-1) and Fas ligand expression in normal pancreas and pancreatic tumors. Implications for immune privilege and immune escape. Cancer 2002; 94: 2552-2560.

100. Fokkema E, Timens W, de Vries EG, de Jong S, Fidler V, Meijer C et al. Expression and prognostic implications of apoptosis-related proteins in locally unresectable non-small cell lung cancers. Lung Cancer 2006; 52: 241-247.

101. Fathi M, Amirghofran Z, Shahriari M. Soluble Fas and Fas ligand and prognosis in children with acute lymphoblastic leukemia. Med Onc 2012; 29: 2046-2052.

102. Charafe-Jauffret E, Ginestier C, Birnbaum D. Breast cancer stem cells: tools and models to rely on. BMC Cancer 2009; 9: 202.

103. Reya T, Morrison SJ, Clarke MF, Weissman IL. Stem cells, cancer, and cancer stem cells. Nature 2001; 414: 105-111.

104. Creighton CJ, Li X, Landis M, Dixon JM, Neumeister VM, Sjolund A et al. Residual breast cancers after conventional therapy display mesenchymal as well as tumor-initiating features. Proc Natl Acad Sci USA 2009; 106: 13820-13825.

105. Frank NY, Schatton T, Frank MH. The therapeutic promise of the cancer stem cell concept. J Clin Invest 2010; 120: 41-50.

106. Gupta PB, Chaffer CL, Weinberg RA. Cancer stem cells: mirage or reality? Nat Med 2009; 15: $1010-1012$.

107. Corsini NS, Sancho-Martinez I, Laudenklos S, Glagow D, Kumar S, Letellier E et al. The death receptor CD95 activates adult neural stem cells for working memory formation and brain repair. Cell Stem Cell 2009; 5: 178-190.

108. Richards M, Tan SP, Tan JH, Chan WK, Bongso A. The transcriptome profile of human embryonic stem cells as defined by SAGE. Stem Cells 2004; 22: 51-64.

109. Shell S, Park SM, Radjabi AR, Schickel R, Kistner EO, Jewell DA et al. Let-7 expression defines two differentiation stages of cancer. Proc Natl Acad Sci USA 2007; 104 $11400-11405$.

110. Hau A, Ceppi P, Peter ME. CD95 Is Part of a let-7/p53/miR-34 Regulatory Network. PLoS One 2012; 7: e49636.

111. Zheng H, Li W, Wang Y, Xie T, Cai Y, Wang Z et al. miR-23a inhibits E-cadherin expression and is regulated by AP-1 and NFAT4 complex during Fas-induced EMT in gastrointestinal cancer. Carcinogenesis 2014; 35: 173-183.

112. Zheng HX, Cai YD, Wang YD, Cui XB, Xie TT, Li WJ et al. Fas signaling promotes motility and metastasis through epithelial-mesenchymal transition in gastrointestinal cancer. Oncogene 2013; 32: 1183-1192.

113. Zheng H, Li W, Wang Y, Liu Z, Cai Y, Xie T et al. Glycogen synthase kinase-3 beta regulates Snail and beta-catenin expression during Fas-induced epithelial-mesenchymal transition in gastrointestinal cancer. Eur J Cancer 2013; 49: 2734-2746.

114. Mani SA, Guo W, Liao MJ, Eaton EN, Ayyanan A, Zhou AY et al. The epithelialmesenchymal transition generates cells with properties of stem cells. Cell 2008; 133 704-715.

115. Ceppi P, Hadji A, Kohlhapp F, Pattanayak A, Hau A, Xia L et al. CD95 and CD95L promote and protect cancer stem cells. Nat Commun 2014; 5: 5238.

116. Park SM, Gaur AB, Lengyel E, Peter ME. The miR-200 family determines the epithelial phenotype of cancer cells by targeting the E-cadherin repressors, ZEB1 and ZEB2. Genes Dev 2008; 22: 894-907.

117. Shimono Y, Zabala M, Cho RW, Lobo N, Dalerba P, Qian D et al. Downregulation of miRNA-200c links breast cancer stem cells with normal stem cells. Cell 2009; 138: $592-603$.

118. Schickel R, Park SM, Murmann AE, Peter ME. mir-200c regulates induction of apoptosis through CD95 by targeting FAP-1. Mol Cell 2010; 38: 908-915.
119. Hadji A, Ceppi P, Murmann AE, Brockway S, Pattanayak A, Bhinder B et al. Death induced by CD95 or CD95 ligand elimination. Cell Rep 2014; 10: 208-222.

120. Peter ME. DICE: A novel tumor surveillance mechanism - a new therapy for cancer? Cell Cycle 2014; 13: 1373-1378.

121. Friesen C, Fulda S, Debatin KM. Cytotoxic drugs and the CD95 pathway. Leukemia 1999; 13: $1854-1858$.

122. Kaufmann SH, Earnshaw WC. Induction of apoptosis by cancer chemotherapy. Exp Cell Res 2000; 256: 42-49.

123. Yu $\mathrm{F}$, Yao $\mathrm{H}$, Zhu $\mathrm{P}$, Zhang $X$, Pan $Q$, Gong $C$ et al. let-7 regulates self renewal and tumorigenicity of breast cancer cells. Cell 2007; 131: 1109-1123.

124. Visvader JE, Lindeman GJ. Cancer stem cells: current status and evolving complexities. Cell Stem Cell 2012; 10: 717-728.

125. Ametller E, Garcia-Recio S, Costamagna D, Mayordomo C, Fernandez-Nogueira P, Carbo $\mathrm{N}$ et al. Tumor promoting effects of CD95 signaling in chemoresistant cells. Mol Cancer 2010; 9: 161.

126. Brahmer JR, Tykodi SS, Chow LQ, Hwu WJ, Topalian SL, Hwu P et al. Safety and activity of anti-PD-L1 antibody in patients with advanced cancer. N Engl $J$ Med 2012; 366 2455-2465.

127. Topalian SL, Hodi FS, Brahmer JR, Gettinger SN, Smith DC, McDermott DF et al. Safety, activity, and immune correlates of anti-PD-1 antibody in cancer. N Engl J Med 2012; 366 : 2443-2454

128. Lipson EJ, Sharfman WH, Drake CG, Wollner I, Taube JM, Anders RA et al. Durable cancer regression off-treatment and effective reinduction therapy with an anti-PD-1 antibody. Clin Cancer Res 2013; 19: 462-468.

129. Hamid O, Robert C, Daud A, Hodi FS, Hwu WJ, Kefford R et al. Safety and tumor responses with lambrolizumab (anti-PD-1) in melanoma. N Engl J Med 2013; 369 . 134-144.

130. Konno R, Takano T, Sato S, Yajima A. Serum soluble fas level as a prognostic factor in patients with gynecological malignancies. Clin Cancer Res 2000; 6: 3576-3580.

131. Osorio LM, Aguilar-Santelises M, De Santiago A, Hachiya T, Mellstedt $H$, Jondal M. Increased serum levels of soluble Fas in progressive B-CLL. Eur J Haematol 2001; 66 : 342-346.

132. Muschen M, Moers C, Warskulat U, Niederacher D, Betz B, Even J et al. CD95 ligand expression in dedifferentiated breast cancer. J Pathol 1999; 189: 378-386.

133. Mizutani Y, Hongo F, Sato N, Ogawa O, Yoshida O, Miki T. Significance of serum soluble Fas ligand in patients with bladder carcinoma. Cancer 2001; 92: 287-293.

134. Mizutani Y, Yoshida O, Ukimura O, Kawauchi A, Bonavida B, Miki T. Prognostic significance of a combination of soluble Fas and soluble Fas ligand in the serum of patients with Ta bladder cancer. Cancer Biother Radiopharm 2002; 17: 563-567.

135. Chopin D, Barei-Moniri R, Maille P, Le Frere-Belda MA, Muscatelli-Groux B, Merendino N et al. Human urinary bladder transitional cell carcinomas acquire the functional Fas ligand during tumor progression. Am J Pathol 2003; 162: 1139-1149.

136. Yang $\mathrm{H}$, Li H, Wang Z, Gao J, Guo Y. Is urinary soluble Fas an independent predictor of non-muscle-invasive bladder cancer? A prospective chart study. Urol Int 2013; 91 456-461.

137. Gutierrez LS, Eliza M, Niven-Fairchild T, Naftolin F, Mor G. The Fas/Fas-ligand system: a mechanism for immune evasion in human breast carcinomas. Breast Cancer Res Treat 1999; 54: 245-253.

138. Mottolese M, Buglioni S, Bracalenti C, Cardarelli MA, Ciabocco L, Giannarelli D et al Prognostic relevance of altered Fas (CD95)-system in human breast cancer. Int $\mathrm{J}$ Cance 2000; 89: 127-132.

139. Reimer T, Herrnring C, Koczan D, Richter D, Gerber B, Kabelitz D et al. FasL:Fas ratio-a prognostic factor in breast carcinomas. Cancer Res 2000; 60: 822-828.

140. Mullauer L, Mosberger I, Grusch M, Rudas M, Chott A. Fas ligand is expressed in norma breast epithelial cells and is frequently up-regulated in breast cancer. J Pathol 2000; 190 $20-30$

141. Bewick M, Conlon M, Parissenti AM, Lee H, Zhang L, Gluck S et al. Soluble Fas (CD95) is a prognostic factor in patients with metastatic breast cancer undergoing high-dose chemotherapy and autologous stem cell transplantation. J Hematother Stem Cell Res 2001 10: 759-768.

142. Munakata S, Watanabe O, Ohashi K, Morino H. Expression of Fas ligand and bcl-2 in cervical carcinoma and their prognostic significance. Am J Clin Pathol 2005; 123: 879-885.

143. Song E, Chen J, Ouyang N, Su F, Wang M, Heemann U. Soluble Fas ligand released by colon adenocarcinoma cells induces host lymphocyte apoptosis: an active mode of immune evasion in colon cancer. Br J Cancer 2001; 85: 1047-1054.

144. Wu SF, Zhang JW, Qian WY, Yang YB, Liu Y, Dong Y et al. Altered expression of survivin, Fas and FasL contributed to cervical cancer development and metastasis. Eur Rev Med Pharmacol Sci 2012; 16: 2044-2050.

145. Lerma E, Romero M, Gallardo A, Pons C, Munoz J, Fuentes J et al. Prognostic significance of the Fas-receptor/Fas-ligand system in cervical squamous cell carcinoma. Virchows Arch 2008; 452: 65-74.

146. Mann B, Gratchev A, Bohm C, Hanski ML, Foss HD, Demel G et al. FasL is more frequently expressed in liver metastases of colorectal cancer than in matched primary carcinomas. Br J Cancer 1999; 79: 1262-1269. 
147. Belluco C, Esposito G, Bertorelle R, Alaggio R, Giacomelli L, Bianchi LC et al. Fas ligand is up-regulated during the colorectal adenoma-carcinoma sequence. Eur J Surg Oncol 2002; 28: $120-125$.

148. Nozoe T, Yasuda M, Honda M, Inutsuka S, Korenaga D. Fas ligand expression is correlated with metastasis in colorectal carcinoma. Oncology 2003; 65: 83-88.

149. Zhang W, Ding EX, Wang Q, Zhu DQ, He J, Li YL et al. Fas ligand expression in colon cancer: a possible mechanism of tumor immune privilege. World J Gastroenterol 2005; 11: 3632-3635.

150. Li H, Fan X, Stoicov C, Liu JH, Zubair S, Tsai E et al. Human and mouse colon cancer utilizes CD95 signaling for local growth and metastatic spread to liver. Gastroenterol 2009; 137: 934-944.

151. Hoogwater FJ, Snoeren N, Nijkamp MW, Gunning AC, van Houdt WJ, de Bruijn MT et al. Circulating CD95-ligand as a potential prognostic marker for recurrence in patients with synchronous colorectal liver metastases. Anticancer Res 2011; 31: 4507-4512.

152. Kykalos S, Mathaiou S, Karayiannakis AJ, Patsouras D, Lambropoulou M, Simopoulos C. Tissue expression of the proteins fas and fas ligand in colorectal cancer and liver metastases. J Gastrointest Cancer 2012; 43: 224-228.

153. Saigusa S, Tanaka K, Ohi M, Toiyama Y, Yasuda H, Kitajima T et al. Clinical implications of Fas/Fas ligand expression in patients with esophageal squamous cell carcinoma following neoadjuvant chemoradiotherapy. Mol Clin Oncol 2015; 3: 151-156.

154. Tsutsumi S, Kuwano H, Shimura T, Morinaga N, Mochiki E, Asao T. Circulating soluble Fas ligand in patients with gastric carcinoma. Cancer 2000; 89: 2560-2564.

155. Ichikura T, Majima T, Uchida T, Okura E, Ogawa T, Mochizuki H. Plasma soluble Fas ligand concentration: decrease in elderly men and increase in patients with gastric carcinoma. Oncol Rep 2001; 8: 311-314

156. Nagashima H, Mori M, Sadanaga N, Mashino K, Yoshikawa Y, Sugimachi K. Expression of Fas ligand in gastric carcinoma relates to lymph node metastasis. Int J Oncol 2001; 18: 1157-1162.

157. Osaki M, Kase S, Kodani I, Watanabe M, Adachi H, Ito H. Expression of Fas and Fas ligand in human gastric adenomas and intestinal-type carcinomas: correlation with proliferation and apoptosis. Gastric Cancer 2001; 4: 198-205.

158. Zheng HC, Sun JM, Wei ZL, Yang XF, Zhang YC, Xin Y. Expression of Fas ligand and caspase- 3 contributes to formation of immune escape in gastric cancer. World $J$ Gastroenterol 2003; 9: 1415-1420

159. Nada O, Abdel-Hamid M, Ismail A, El Shabrawy L, Sidhom KF, El Badawy NM et al. The role of the tumor necrosis factor (TNF)-Fas L and HCV in the development of hepatocellular carcinoma. J Clin Virol 2005; 34: 140-146.

160. Tanaka M, Suda T, Haze K, Nakamura N, Sato K, Kimura F et al. Fas ligand in human serum. Nat Med 1996; 2: 317-322.

161. El Bassiouny AE, El-Bassiouni NE, Nosseir MM, Zoheiry MM, El-Ahwany EG, Salah F et al. Circulating and hepatic Fas expression in HCV-induced chronic liver disease and hepatocellular carcinoma. Medscape J Med 2008; 10: 130.

162. Abrahams VM, Straszewski SL, Kamsteeg M, Hanczaruk B, Schwartz PE, Rutherford TJ et al. Epithelial ovarian cancer cells secrete functional Fas ligand. Cancer Res 2003; 63 5573-5581.

163. Munakata S, Enomoto T, Tsujimoto M, Otsuki Y, Miwa H, Kanno H et al. Expressions of Fas ligand and other apoptosis-related genes and their prognostic significance in epithelial ovarian neoplasms. Br J Cancer 2000; 82: 1446-1452.

164. Taylor DD, Lyons KS, Gercel-Taylor C. Shed membrane fragment-associated markers for endometrial and ovarian cancers. Gynecol Oncol 2002; 84: 443-448.

165. Chaudhry P, Srinivasan R, Patel FD, Gopalan S, Majumdar S. Serum soluble Fas levels and prediction of response to platinum-based chemotherapy in epithelial ovarian cancer. Int J Cancer 2008; 122: 1716-1721.

166. Bellone G, Smirne C, Carbone A, Mareschi K, Dughera L, Farina EC et al. Production and pro-apoptotic activity of soluble CD95 ligand in pancreatic carcinoma. Clin Cancer Res 2000; 6: 2448-2455.
167. Hazar V, Berber Z, Pestereli E, Coskun M, Yesilipek A, Karpuzoglu G et al. Clinical importance of circulating and cellular expression levels of Fas and Fas ligand in pediatric patients with lymphoproliferative malignancies. Pediatr Hematol Oncol 2005; 22: 247-256.

168. Macher-Goeppinger S, Bermejo JL, Wagener N, Hohenfellner M, Haferkamp A, Schirmacher $\mathrm{P}$ et al. Expression and prognostic relevance of the death receptor CD95 (Fas/AP01) in renal cell carcinomas. Cancer Lett 2011; 301: 203-211.

169. Somma P, Lo Muzio L, Mansueto G, Delfino M, Fabbrocini G, Mascolo M et al. Squamous cell carcinoma of the lower lip: FAS/FASL expression, lymphocyte subtypes and outcome. Int J Immunopathol Pharmacol 2005; 18: 59-64.

170. Sejima T, Morizane S, Hinata N, Yao A, Isoyama T, Saito M et al. Fas expression in renal cell carcinoma accurately predicts patient survival after radical nephrectomy. Urol Int 2012; 88: 263-270.

171. Muraki Y, Tateishi A, Seta C, Fukuda J, Haneji T, Oya R et al. Fas antigen expression and outcome of oral squamous cell carcinoma. Int J Oral Maxillofac Surg 2000; 29: 360-365.

172. Fang L, Sun L, Hu FF, Chen QE. Effects of FasL expression in oral squamous cell cancer. Asian Pac J Cancer Prev 2013; 14: 281-285.

173. Hara S, Miyake H, Nakamura I, Arakawa S, Kamidono S, Hara I. Increased Fas ligand expression in the tumor tissue and serum of patients with testicular germ cell tumors with seminomatous elements. Urology 2001; 58: 471-476.

174. Baldini E, Ulisse S, Marchioni E, Di Benedetto A, Giovannetti G, Petrangeli E et al. Expression of Fas and Fas ligand in human testicular germ cell tumours. Int J Androl 2009; 32: $123-130$.

175. Rzeszutko M, Rzeszutko W, Dziegiel P, Balcerzak W, Kaliszewski K, Bolanowski M. Expression of FAS/APO 1/CD 95 in thyroid tumors. Folia Histochem Cytobiol 2007; 45: 87-91.

176. Owonikoko TK, Hossain MS, Bhimani C, Chen Z, Kim S, Ramalingam SS et al. Soluble FAS ligand as a biomarker of disease recurrence in differentiated thyroid cancer. Cancer 2013; 119: 1503-1511.

177. Lin HC, Lai PY, Lin YP, Huang JY, Yang BC. Fas ligand enhances malignant behavior of tumor cells through interaction with Met, hepatocyte growth factor receptor, in lipid rafts. J Biol Chem 2012; 287: 20664-20673.

178. Liu Q, Tan Q, Zheng Y, Chen K, Qian C, Li N et al. Blockade of Fas signaling in breast cancer cells suppresses tumor growth and metastasis via disruption of Fas signalinginitiated cancer-related inflammation. J Biol Chem 2014; 289: 11522-11535.

179. Nakamoto $\mathrm{Y}$, Kaneko S, Fan H, Momoi T, Tsutsui H, Nakanishi $\mathrm{K}$ et al. Prevention of hepatocellular carcinoma development associated with chronic hepatitis by anti-fas ligand antibody therapy. J Exp Med 2002; 196: 1105-1111.

180. Park SM, Rajapaksha TW, Zhang M, Sattar HA, Fichera A, Ashton-Rickardt PG et al. CD95 signaling deficient mice with a wild-type hematopoietic system are prone to hepatic neoplasia. Apoptosis 2008; 13: 41-51.

181. Cai Z, Yang F, Yu L, Yu Z, Jiang L, Wang $Q$ et al. Activated T cell exosomes promote tumor invasion via Fas signaling pathway. J Immunol 2012; 188: 5954-5961.

182. Mitsiades CS, Poulaki V, Fanourakis G, Sozopoulos E, McMillin D, Wen Z et al. Fas signaling in thyroid carcinomas is diverted from apoptosis to proliferation. Clin Cancer Res 2006; 12: 3705-3712.

(c) (1) (2) This work is licensed under a Creative Commons Attribution-NonCommercial-ShareAlike 3.0 Unported License. The images or other third party material in this article are included in the article's Creative Commons license, unless indicated otherwise in the credit line; if the material is not included under the Creative Commons license, users will need to obtain permission from the license holder to reproduce the material. To view a copy of this license, visit http://creativecommons.org/licenses/by-nc-sa/3.0/ 